Bakhtiyor Amonov

$\mathrm{PhD}$,

Tashkent University of information technologies,

Tashkent, Uzbekistan

amonovb@mail.ru

p-ISSN: 2308-4944 (print) e-ISSN: 2409-0085 (online)

Year: $2016 \quad$ Issue: 9 Volume: 41

Published: $30.09 .2016 \quad$ http://T-Science.org

SECTION 30. Philosophy

\title{
THE PECULIARITIES OF PASSING TO DEMOCRATIC SOCIETY IN UZBEKISTAN
}

\author{
Abstract: In the given article evolution of the theory and practice of democratization in Uzbekistan. \\ Key words: modernization, democratization, society, reforming, concept, political system. \\ Language: English \\ Citation: Amonov B (2016) THE PECULIARITIES OF PASSING TO DEMOCRATIC SOCIETY IN \\ UZBEKISTAN. ISJ Theoretical \& Applied Science, 09 (41): 89-91. \\ Soi: http://s-o-i.org/1.1/TAS-09-41-14 Doi: crossef http://dx.doi.org/10.15863/TAS.2016.09.41.14
}

\section{Introduction}

Notion, tasks and problems of political modernization of society, basis and peculiarities of political modernization in the countries of Uzbekistan, models of political modernization of the world and Uzbekistan's experience, it's theoretical basis.

Political-philosophical analysis, learning appearance and development of theory of political modernization in the examples of countries of East and West, comparing the models and experience of political modernization of the Uzbekistan, the problems of it's improving in future.

Scientific learnt it's external and internal factors connected with conceptional solutions. Explore the matter "Uzbekistan model".

Scientific publications and as will be widely used in processes of education, perfecting basis of theories and practices of political modernization.

Solving the passing period problems plays very important role in modernization of society [1, p.277]. "The question is assigning the realizing functions of strategy in passing period, working out their solving mechanisms and determining each country's peculiarities for realizing it into reality, - writes professor S. Otamurodov. - For modernizing a country and passing to democratic society it is necessary to consider not only promotional degree, but in its turn the mentality of people who are living there" [2, p. 236]. So, during passing period we should pay attention will-power, mentality like other factors of the people. It helps doing successful elaborations. For example it's known to everybody that in Japan, China and South Korea developing steps are passing solidly. In its turn, the Japan, the China and the Korean people is getting great profit from these elaborations.

\section{Materials and Methods}

Deeply analyzing existing factors of politics, we abovementioned that Uzbekistan worked out traditional evolutional way. Considering the features of the conception which worked out by president Islam Karimov gives an opportunity of preventing from arising difficult situations, social conflicts, and instability in our country. They are, in its turn, played an important role while solving arising socialpolitical and economical difficulties solidly and starting elaborations gave its fruits successfully. The peculiarities of solving strategies of passing period problems of Uzbekistan the whole world public recognized and it is called "uzbek" model.

It's known that liberalization - is first step for democracy of society. Each country's spiritual imagination is bounded with its achieving what kind of ideas and purposes, and founding on what kind of mind. The way which Uzbekistan chose is a forming way of citizen's society protected all human advantages and insured their all rights. It is of course, requires gaining several difficulties, complexities, and conflicts.

Firstly, we should say the conflicts between olds and news. Old constitution's bad habits don't want to leave and want to live for a long until taking out it from root. But new constitution ideas deeply 
realizes the necessity of rebuilding society and bounding this necessity to the life-death notion, fate of each citizen, spiritual needs of people, during centuries formed life style and viewpoint, comes to the world as protector idea in any aspect. This idea's life assigned with fighting difficulties even very hard pains of just these old bad habits.

Thirdly, it is an opportunity for presenting their abilities, free life style and human independence. It is social, political, spiritual-mental event which makes us feeling the notion of independence and adding our portion for developing our country.

Fourthly, it is preparing citizens as its active protector and active attendant of just democratic process in the deepening condition of democratic process. It is very difficult and a social event which requires time and condition. Because, for living thinking of the "suffer" how to get rid of the colonial period's bad habits and for overcoming the "obstacle " of earning for living using our mind humanity needs inside will-power, mental will-power.

The level of political cultural, political mind and notions assigns the attendance of human in social life. Where political cultural and political mind is high there people actively and solidly attend to government work. People in meetings, discussions can follow and present their attitudes how the decisions are accepting and how their execution is controlling. And they don't be careless to politicalsocial meetings which belong to their life. And in opposite, they will attend for preparing them, in result for execution of decisions they feel the responsibility for their profit.

There is each nation's applying style to democracy coming from nation's needs, spiritualmental world, each nation's own life and thinking style, historical traditions, attitude to the life and other properties. In this meaning when our president said: "There are appropriate and proper features of democratic process in east which was formed in ancient times. It is impossible passing carelessly it. Indeed the democratic process in east will develop slowly and conformably. In this sphere the attempts of revolution changes brings very unpleasant, even tragedian results. West scientists also called revolution as "wild and ancient form of social development". Naturally, this way is not for us he meant there is forming uzbek factors of establishing democracy [3, 122].

Uzbekistan after achieving independence learnt several countries' ways of democratic development. And in these countries there are exemplary and worthy experiences of democracy. The president of Uzbekistan saying the necessity of dealing with this question coming from each nation's its own national spirit, persuaded that not considering needs of this ancient, rich traditional nation would bring lot of serious problems: "the degree and promotion of democratic changes depends on the appropriateness with peoples' intelligence and social meditation. Historical experience duly authenticated that copying democratic processes blindly from away doesn't give any work. Otherwise, this way causes confusing and dangerous effects." There is fact in abovementioned suggestion. We can see brightly it in the bloody conflicts and political events which happened in 90s of XX century.

It's known from history; not considering native peoples' feelings leads either leader or whole country, and population into dead end. It is impossible establishing west democracy blindly in east countries, imitating to it causes unexpected tragedies. We are watching its bitter effects in example of Tajikistan and especially in Afghanistan. Being careless to inimicality of free and under mask of religion effected on getting quite weak of government and ruling apparatus, letting ruling power without attention brought unfortunates for thousands of families.

If we take in this viewpoint, accepting stability as a situation of steadiness in Uzbekistan, it realizes the opportunities of reconstructing and fertile development. In this case the stability situation is admitted as the necessity of inside and outside positive effects. However the fertility of these changes is managing by the government basing on the factors of gradual development of Uzbekistan society.

After achieving the independence there was important problems for solving in front of Uzbekistan: absolute redirecting of state and society democratic processes to absolute new way. We have to admit particularly, these processes passed with several conflicts and difficulties. Because though Uzbekistan possess all attributes, signs of stateness (as if other countries) in composition of former union, all of those were exist shapely only. There is no any way except this where managing the country staying from Moscow, as well, being advantage of the statue of only leader "party" from all countries' constitution [4, p. 151-166].

The "right" of being sovereign, and structuring of their own development way was written in the main law of that period but for union republics it was not valid.

The constitution (Main Law) of Uzbekistan Republic which accepted on $8^{\text {th }}$ of December in 1992 serves righteous guarantee for democratic direction of country development. On the one hand this document is the result of people's intellect and political mind, on the second hand depicts future sovereign state, also nation's fate. Human's honor which reflects in itself humanness traditions, historical and cultural inherit of nation and its value was taken as a main theme of Main Law. The great importance of humanity is particularly admitted in the Constitution. The highest righteous resolution of relationship between citizen, society and states 
reflects in it and defined main theme of social justice is providing stability in society.

The leader of Uzbekistan often tells the ideas which challenges all people to think about political culture and political activeness which was one of serious problems of democratization of society:"We have to repeat the political activity of our nation doesn't answer to the requirements of world, and still weak. We have to confess that: we can't get rid of from old models. It is getting difficult to apart from bad habits of colonial system and administrativecommand system which all important decisions are accepted from "high", we, common people were only obedient executors, sometimes victim of without thinking accepted decision". So, in this case there is a great facility in front of education and political institutions.

If we analyze the society of Uzbekistan in this viewpoint, we can see clearly those political activities of people are not still in the level of democratic factors. There are still advantages of the political ideas and imaginations of old society in our society. In political activities of citizens is getting very difficult being clear from feeling of passiveness, laziness.

The importance of political elaborations is in our country, nowadays there was created good conditions for setting up to the life the important factors of democracy, for developing their political culture, for increasing social-political activity of public people. There is formed featured value of democratization of political processes in Uzbekistan. I. Karimov deeply analyzing the experiences of independence period and the experiences of leader foreign countries put forwardly the democratic factors of citizens' attending to political processes: "It's known that in any society there are minimum three measures which assigns the level of democracy", - said our President Islam Karimov. These are - people how much being informed from accepting processes of decisions, how much being controlled of government decisions by people, how much attending of people to managing of the state... While we built justice, democratic society we should not forget the reality: one can't establish a democracy and justice by ordering a special decree or order from high. This is very difficult work which realizes by attendance of all people, fist leading wisdoms, different political parties, representatives of public organizations, power, braveness, and cleverness of responsible clerks" [5].

\section{Conclusion}

Increasing citizens political activities, while accepting decision from high peoples' attending themselves widely or by means of their groups is main guarantee of establishing citizens society. Especially, its clear dealing with political freedom elaborations would be difficult while former totalitarian society's inherited complications of administrative-command system will not be deleted from peoples' viewpoint, political mind and practical deeds. Our government's leader gives special attention to attendance of citizens to accepting political decisions. In this case there are enough good conditions in our country, only citizens should attend to the organizations which express their will-power and advantages or by no means, should they attend to accepting processes of political decisions.

\section{References:}

1. Wallerstein I (1999) The End of the World as We Know It: Social Science for the TwentyFirst Century.- Minneapolis: Univ. of Minnesota Press, 1999.- pp. 277.

2. Otamurodov S (2005) The philosophy of development. T.: Academy, 2005. - pp.236.

3. Karimov I (1998) Uzbekistan: national independence, economics, politics, intellect. T.: “Uzbekistan", 1998. - pp.122.

4. Amonov B (2011) An Analysis of the Modernization Process in the Commonwealth of Independent States (CIS). Decision ethics. 2011,VII.3. -New York, USA. -pp.151-166.

5. Karimov I (1998) Uzbekistan: national independence, economics, politics, intellect. T.: "Uzbekistan", 1998. -pp.252.
6. (1994) Modernization: The foreign experience and Russia. Moscow, 1994.

7. (1993) "Steps to the 21st Century," The Japan Times, 1993.

8. Parsons T (1979) The System of Modern Societies, Englewood Cliffs (N.J.). Development theory: Four critical studies. Ed. By Lehman D.L. 1979.

9. (2016) Available: https://www.cia.gov/library/publications/theworld-factbook/geos/rs.html (Accessed: 10.09.2016).

10. (2016)

Available: http://www.globalsecurity.org/military/world/ru ssia/mo-budget.htm (Accessed: 10.09.2016). 